\title{
Türkiye'deki devlet ve vakıf üniversite kampüslerinin sürdürülebilir-ekolojik parametreleri açısından karşılaştırılması
}

\author{
Sema KAYAPINAR KAYA ${ }^{1}$, Murat DAL ${ }^{2, *}$, Ali AŞKIN ${ }^{3}$ \\ ${ }^{1}$ Munzur Üniversitesi, Mühendislik Fakültesi, Endüstri Mühendisliği Bölümü, Aktuluk Kampüsü, Tunceli \\ ${ }^{2}$ Munzur Üniversitesi, Mühendislik Fakültesi, Inşaat Mühendisliği Bölümü, Aktuluk Kampüsü, Tunceli \\ ${ }^{3}$ Munzur Üniversitesi, Mühendislik Fakültesi, Mekatronik Mühendisliği Bölümü, Aktuluk Kampüsü,
} Tunceli

Gelis Tarihi (Recived Date): 16.02 .2018

Kabul Tarihi (Accepted Date): 06.12.2018

\section{Özet}

Bu çalışmada, ülkemizde hızla artan üniversitelerin yeni yapılaşma sürecindeki kampüslerde sürdürülebilir-ekolojik kampüs olma özelliği taşımaları konusunda bir farkındalık amaçlanmıştır. Bu amaçla, Türkiye'deki 5 Devlet Üniversitesi (Boğaziçi, Bülent Ecevit, Karabük, İstanbul Teknik, Ege), 5 Vaklf Üniversitesi (Özyeğin, Yeditepe, Bahçeşehir, Bilgi ve Bilkent) sürdürülebilir-ekolojik kampüs olma kriterleri olan "Enerji Yönetimi”, "Sürdürülebilir Ulaşım”, "Atık Değerlendirme”, "Su Yönetimi”, "Çevre ve Peyzaj Yönetimi”, "Sürdürülebilir Eğitim” parametreleri açısından 10 farkl üniversite kampüsü değerlendirilmiştir.

Anahtar kelimeler: Sürdürülebilir, ekolojik, kampüs, üniversite.

\section{Comparison of the public and private university campusses in Turkey in terms of the sustainable - ecological parameters}

\begin{abstract}
In this study, it is aimed to highlight the properties of the increasing number of the university campusses in Turkey in terms of sustainable and ecological properties. 5 public (Boğaziçi, Bülent Ecevit, Karabük, İstanbul Teknik, Ege) and 5 private (Özyeğin, Yeditepe, Bahçeşehir, Bilgi and Bilkent) universities are investigated in terms of

Sema KAYAPINAR KAYA, semakayapinar@munzur.edu.tr, http://orcid.org/0000-0002-8575-4965

*Murat DAL, muratdal@munzur.edu.tr, http://orcid.org/0000-0001-5330-1868

Ali AŞKIN, aliaskin@munzur.edu.tr, http://orcid.org/0000-0001-8571-3680
\end{abstract}


sustainable and ecological campus criterias such as "Energy Management", "Sustainable Transportation", "Waste Management”, "Water Management", "Environmental Management" and "Sustainable Education".

Keywords: Sustainable, ecological, campus, university.

\section{Giriş}

Dünyada artan nüfus ile birlikte, köylerden kentlere göç artmış, bunu takiben düzensiz ve plansız kentleşme, alt yapı yetersizliği ve atıkların artışı, hızla tükenen fosil enerji kaynakları vb. birçok çevre sorunlarını beraberinde getirmiştir. Artan nüfusun ihtiyaçlarının karşılanması için teknolojik gelişimle birlikte endüstrileşmenin de artması gerekmektedir. Plansız endüstrileşme ve hızlı nüfus artışı, plansız kentleşmenin bir sonucu olarak ortaya çıkmıştır. Nüfus artışıyla birlikte tüketim oranının artması atık sayısı artırmakta, atıklar doğru şekilde imha edilmediği için birçok çevre sorunuyla karşı karşıya kalınmaktadır. Dünyadaki çevre kirliliğinin büyük bir kısmının son 35 yılda meydana geldiği ve bunun \% 50' sinin hızlı nüfus artışından kaynaklı olduğu görülmektedir [1]. Ev ve işyerlerinden çevreye zarar veren yakıtların kullanılması, evsel atıkların geri dönüştürülmeden doğaya atılması, kimyasal ve biyolojik silah kullanımı, bilinçsiz avlanma, ağaçların kesilmesi ve yangınlar, kullanılan kimyasal ilaçların atmosfere yayılması, teknolojik cihazlardan kaynaklı radyasyon atıkları insan kaynaklı temel çevre sorunlarıdır.

Plansız ve hızla artan sanayileşme, doğal kaynakların hızlı bir şekilde tükenmesine, üretim süreci sonunda ortaya çıkan karbon gazı ve atıkların önlem alınmadan doğaya atılması, çevre kirliliğinin oluşmasına zemin hazırlamıştır. Sanayi tesislerinden ortaya çıkan atıkların düzenli olarak bertaraf edilmemesi, üretimde çıkan zehirli ve kimyasal gazlar, enerji kaynaklarının hızlı bir şekilde tüketilmesiyle birçok çevresel sorunu beraberinde getirmiştir.

Büyük şehirlerde yaşanan çevre sorunları 1960'lı yılların ortalarında toplum tarafından fark edilmeye ve tartışılmaya başlanmıştır. 20 yy. başlarında çevre ve ekolojik hareket Avrupa başta olmak üzere ve gelişmekte olan ülkeler tarafından farkındalık oluşturulmaya çalışılmıştır. Çevre sorunlarının artışıyla "sürdürülebilir" ve "ekolojik" terimleri günlük hayatımıza girmeye başlamıştır. İlk olarak 1970 yılında uluslararası alanda ortaya çıkan "Sürdürülebilirlik" kavramı çevrenin korunması ve ekolojik dengenin sağlanması olarak tanımlanmıştır. 1972 yılında İsviçre Stockholm Konferansında düzenlenen "insan faaliyetlerinin çevreye etkisi" konusu ele alınmış ve çevreye verilen zararlarına dikkat çekilmiştir. 1987 yılında Montreal Protokolü’nde ozon tabakasını incelten maddelere ilişkin bir protokol imzalanarak, zararlı gazların tüketiminin azaltılması kararı alınmıştır [2]. 1992 yılında Brezilya'da Birleşmiş Milletler tarafından düzenlenen kalkınma kongresinde sürdürülebilir kalkınma kavramı ve çevre dengesi üzerinde durulmuştur. 1997 yılında 189 ülke tarafından imzalanan Kyoto Protokolünde sera gazı emisyonu 2012 yılına kadar azaltılmasına karar verilmiştir [3]. Sürdürülebilirlik temelde doğal çevrenin korunumunu ve sürekliliğini ön planda tutan, içerisinde sosyal ve ekonomik boyutları da içerisinde barındıran oldukça geniş bir kavramdır. Sürdürülebilir kalkınma, ancak çevresel, ekonomik ve sosyal sürdürebilirlik birlikte sağlandığ takdirde gerçekleşecektir [4].

Sürdürülebilir kalkınmanın eğitim boyutu, ilk kez 1972 yılındaki Stockholm Konferansı'nda gündeme getirilmiştir [5]. Birleşmiş Milletler 2005-2014 yıllarını kapsayan süreçte sürdürülebilir Kalkınma Eğitim sürecini desteklemiştir [6]. 
Sürdürülebilir eğitimde üniversitelere büyük görevler düşmektedir. Üniversiteler, topluma yenilikçi ve öncü rollerinden dolayı sürdürülebilir ve ekolojik uygulamalar ile toplumda sürdürülebilir bir yaşam stilinin yaygınlaşmasında katkı sağlayan en önemli eğitim-öğretim kurumlarıdır. Dolayısıyla, sürdürülebilir üniversite, sürdürülebilir ve ekolojik kampüs uygulamaları dünya genelinde hızla artan bir trend haline gelmiştir. Başta Avrupa da bulunan üniversiteler olmak üzere tüm dünyada yükselen bir trend olan "sürdürülebilir ve ekolojik kampüs" uygulamaları; çevreye duyarlı, enerji tasarrufunu minimize eden, etkili atık yönetimine sahip, doğaya-dost ürün ve malzemeler kullanan, sürdürülebilir kalkınmaya katkı sağlayan kampüsler yaratmaktır. Sürdürülebilir ve ekolojik kampüs uygulamaları ile üniversite ekonomik olarak kendi ayakları üzerinde durabilecek, küresel iklim değişikliğine ve çevresel problemlere karşı dayanım gösterecek, toplumu bilinçlendirerek sosyal sorumluluk görevlerini yerine getirecektir.

Sürdürülebilir kampüslere ilgi arttıkça, sürdürülebilir uluslararası indeksler kullanılmaya başlanmıştır. Bunlar; Yeşil Lig (Green League), Çevresel ve Sosyal Sorumluluk İndeksi (Environmental and Social Responsibility Index), Yeşil Ölçüm (GreenMetric) değerlendirme yöntemleridir [7]. Bunlar içerisinde en çok kullanılan ve sürdürülebilir kampüs uygulamalarında bir ilk olan UI GreenMetric sıralama modelidir. UI Greenmetric sıralama modelinin ortaya çıkmasındaki temel amaç, yükseköğretim kurumlarında, artan çevre sorunları (su kirliliği, toprak ve hava kirliliği vb.), yenilenemez enerji kaynaklarının hızla tükenmesi, küresel ısınmayla ortaya çıkan kuraklık, biyolojik çeşitliliğin azalması, mevsim ve iklim değişiklikleri, ekolojik dengenin bozulması gibi pek çok etmen yer almaktadır. Endonezya Üniversitesi tarafından 2010 yılında hayata geçirdiği UI Greenmetric modeli, Yükseköğretim kurumlarının çevreye duyarlı ve sürdürülebilir olması için, yeşil ölçüm kategori ve göstergeleri geliştirilmiştir. Toplamda 6 ana kategori ve 53 gösterge olmak üzere oluşturulan bu model, "çevre ve ekolojik duyarlılık, ekonomi ve öğretim konularını içine alacak şekilde yapılandırılmıştır. Göstergeler sırasıyla, kampüs yerleşimi ve altyapı, enerji ve iklim değişikliğii, atık yönetimi, su yönetimi, çevre dostu ve ulaşım olanakları ve öğretim şeklindedir [8]. Bu model sayesinde üniversite yöneticileri ve çalışanlarının, "küresel 1sınma", "enerji", "su yönetimi ve tasarrufu", "atık geri dönüşümü", "yeşil ulaşım ve çevre" gibi konularda farkındalık oluşturulması amaçlanmıştır. Küresel ısınma, atmosfere salınan karbondioksit gibi sera gazı etkisi yaratan gazların, dünyanın 1sıl dengesini bozması sonucu; yer kabuğu ve denizlerin ortalama sıcaklığının artmasına neden olan bir çevre sorunudur. Üniversiteler, bu model kapsamında yer alan "enerji ve iklim değişiklikleri" ana kategorisi altında "enerji tasarrufu", "sera gazı emisyonu azaltma ve uyum politikası", "kampüs içi karbon ayak izi oranı", "yeşil ve akıllı bina uygulamaları", "enerji tasarruflu cihaz kullanımı" kampüs içerisinde uygulayarak küresel 1sınmaya tehdit olacak unsurları azaltması amaçlamaktadır. Su yönetimi ve tasarrufu, kampüs içinde kullanılan su kaynaklarının plan ve programlı bir şekilde geliştirilmesi, dağıtılması ve kullanılması olarak ifade edilmektedir. Sürdürülebilir ve ekolojik kampüs olma yolunda, su ayak izini takip hesaplayarak, suyun etkin bir şekilde kullanımını sağlamayı amaçlamaktadır. Fakülteler yemekhaneleri başta olmak üzere lavabolardan ortaya çıkan su "Gri Su" olarak tanımlanmaktadır. Suyun etkin şekilde yönetimi amacıyla "Gri Su" arındırma sistemleri geliştirilerek sürdürülebilir üniversite olma yolunda yeni adımlar atılmaktadır. Sürdürülebilir kampüs olma yolunda büyük bir baskı oluşturan ve gün geçtikçe artan atık sorunu, atıkların etkin bir şekilde yönetimi ile gerçekleşmektedir. Kampüs içinde ortaya çıkan plastik, cam, kağıt türü geri kazanılabilecek atık türleri için geri kazanım yöntem ve teknikleri geliştirilmesi, atık yönetimi için elzem bir adımdır. Ekolojik ve 
çevreye duyarlı kampüs olma yolunda atıkların etkin şekilde bertaraf edilmesi ve geri kazanım yöntemlerinin geliştirilmesi gerekmektedir. Hava kirliliğinin bilincinin artması ve karbon dioksit gazının çevreye verdiği zararlardan dolayı, kampüs içinde temiz bir hava sahası oluşturmak elzem bir duruma gelmektedir. Kampüs içinde temiz hava sahasını sağlamak için, fosil yakıtlı araçların kullanımının azaltılarak yerlerine çevreye dost, elektrik ve temiz enerji kaynaklarını kullanan taşıtların yaygınlaştırılması gerekmektedir. Sürdürülebilir ve ekolojik üniversite kampüsleri; binalarında kullandıkları enerji tüketimini ve karbon gazı emisyonunu azaltarak, en önemli çevre sorunlarından küresel ısınma ve iklim değişiklerine karşı önlem almayı amaçlamaktadır. Enerji kaynağı olarak fosil yakıtların kullanılması, başta sera gazı etkisi yaratan gazların salınımını artırarak küresel ısınmaya neden olmaktadır. Ayrıca sürdürülebilir kampüs binalarında kullandıkları çevreye dost malzeme kullanılarak ve katı ve sıvı atık yönetimini iyileştirerek çevreye daha duyarlı ve ekolojik kampüs uygulamalarına katkı sağlanmaktadır.

Günümüzde sürdürülebilir ve ekolojik kampüs uygulamalarına örnek verecek olursak; ABD bulunan Stanford üniversitesi, binalarını sensör tabanlı aydınlatma, dörtlü boru sistemi ile 1sıtma ve soğutma bölgesi, yüksek aydınlatma teknolojisiyle geliştirerek \%38'e kadar enerji tasarrufu sağlanmıştır [9]. Berkeley Üniversitesi, lavabolarına yerleştirdiği otomatik rezervuar ile WC'lerdeki su tüketimini 3,6 galondan 1,6 galona indirgemiştir. Ayrıca su kullanımını takip etmek amacıyla, binalarda su sayacı sistemi kullanılmıştır. Su koruma laboratuvarı kurularak, su soğutma sis ve vakumlu su pompalama sistemleri geliştirilmiş, bu sayede kampüste su tüketimi \%32 oranında azaltılmıştır [10]. Nottingham Üniversitesi, İngiltere, Çin ve Malezya'daki kampüslerinde yeşil hava sahasını koruma amacıyla, öğrenci ve çalışanlara uzun dönemlik bisiklet kiralama programı sunmuş, toplu taşımayı teşvik etmek için indirimli otobüs bileti uygulamasına geçmiş, kampüs içinde elektrikli araçlar kullanılmıştır [11]. Elektrik enerjisi karşılanamadığı durumda, güneş enerjisinin kullanıldığı en iyi sistem, ABD'nin Kalifornia eyaletinde bulunan Southwest Kolejinde geliştirilmiştir. Bu sistem 2008 yılında kurulmuş ve 4 MW'lık güneş enerjisine sahip fotovoltaik bir sistemdir. Bu sistem oldukça kapsamlı geliştirilmiştir ve elektrik enerjisi üretilmemekte, 1sı enerjisine de dönüştürülerek kampüs ısıtmasında kullanılmaktadır [12].

\section{Sürdürülebilir-ekolojik kampüs üzerine yapılan literatür çalışmaları}

Sürdürülebilir kampüs ile ilgili yapılmış olan literatür çalışmaları son 10 yılda oldukça yaygınlaşmıştır. $\mathrm{Bu}$ alanda; [13] sürdürülebilir üniversitelerde uygulanması gereken politikalar ve yönetmenlikler üzerine bir genel çalışma sistematiği oluşturmuştur. Buna göre "ahlaki yükümlülük", "sürdürülebilir fiziksel operasyonlar", "sürdürülebilir araştırmaya teşvik", "kamuya açık hizmetler", "hükümetle ortaklık", "sosyal toplum kurumlarıyla iş birliğgi", "farklı disiplinler arası eğitim”, "ekolojik okur yazarlık" olmak üzere 8 kategoride sürdürülebilir üniversite politikaları değerlendirilmiştir [14], bu parametreler 1şığında sürdürülebilir değerlendirme kriterlerini göz önüne alarak güçlü ve zayıf yönler analiz edilmiştir. Üniversiteler de "yerel ve sosyal sorumluluk", "sürdürülebilir eğitim ve öğretim" ve "çevresel yönetim sistemleri" olarak üç kategoride sürdürülebilirlik analiz edilmiştir. Çevresel yönetim sistemleri içerisinde yeşil binalardaki enerji etkinliği, geri dönüşüm ve atık yönetimi, sürdürülebilir ulaşım ele alınırken; yerel ve sosyal sorumluluk içerisinde kampüs içindeki topluluklar (öğrenciler, idari personel, akademik personel), sosyal adalet, sürdürülebilir çevre için oluşturulan topluluklar ve aktiviteler; sürdürülebilir eğitim ve araştırma içinde, üniversitede ekolojik ve çevre konulu kongreler, seminerler ve çalışma aktiviteleri yer almaktadır 
[15]. Üniversitelerde sürdürülebilirliği anlamak amacıyla anketler uygulayarak, bu konuyla ilgili daha kapsamlı amaçlar ve politikalar ortaya konulmasını öngörmüştür [16]. Greenmetric anket yöntemine yeni göstergeler eklenerek, kriterler yeniden oluşturulmuştur [17].

Yeşil bina kampüs uygulamaları başta Avrupa olmak üzere dünya genelinde yaygın olarak kullanılmaktadır. Doğaya zarar vermeyen ve çevreci malzemelerin kullanıldığı yeşil binalar, kendi enerjisini kendisi üreterek, doğayı koruma ve konforlu bir yaşam sunmayı sağlamaktadır. Günümüzde yeşil bina uygulamalarının objektif ve somut olarak ortaya konulması için yeşil-ekolojik bina sertifikasyon sistemleri geliştirilmiştir, Bunlar içinde en bilinenleri sırasıyla; LEED (Leadership in Energy Efficiency Design), BREEAM (Building Research Establishment Environmental Assessment Method), GreenStar vb. sertifikasyon sistemlerdir. Bu sistemler yeşil bina için gerekli olan kriterleri tanımlayarak, bütünsel ve çevreci bir bina tasarım yöntemini geliştirmeyi amaçlamaktadır. LEED sertifika programı 1998 yılında Amerikan Yeşil Binalar Konseyi tarafından Amerika' da ortaya çıkmıştır. LEED, yenilik ve tasarım, iç ortam hava kalitesi, malzeme ve kaynakların kullanımı, sürdürülebilir yer planı, suyun verimli kullanılması, enerji verimliliği, malzeme ve kaynak kullanımı kriterlerini temel alacak şekilde değerlendirme yapılmaktadır [18]. LEED sertifika sistemi, ülkemizde son 10 yıldır kullanılmaya başlanmıştır. Bu kapsamda 2012 yılında ilk kez Bilkent Üniversitesi Kandilli Rasathanesinde yeşil bina uygulamalarına geçerek, Gold Leed sertifika hakkına sahip olmuştur. Binada 1sıtma ve soğutma için temiz enerji kaynaklarından elektrik enerjisinden faydalanılmıştır. Ayrıca ısıtma için yenilenebilir enerji kaynaklarından güneş enerjisi panelleri kullanılmıştır, gri sulama teknikleri kullanılarak yağmur suyu filtrelenerek geri kazanımı sağlanmıştır [19]. Amerika' da bulunan Arizona Üniversitesi Çevre ve doğal kaynaklar binası LEED sertifikasına sahiptir. Binada gri su kullanımı ve yağmur suyu toplama sistemi sayesinde, yılda kullanılan su miktarını \% 40 oranında azaltmıştır. Hazırladıkları sistem ile her yıl 260.000 galonluk yağmur suyu depolayabilmektedir. Güneş enerjisinden faydalanmak amacıyla, fotovoltaiklere kıyasla verimliliği ikiye katlayan yeni bir "teleskop güneş paneli" geliştirmişlerdir. Bu cihaz fotonları (hafif parçacıklar) konsantre ederek daha fazlasını güneş hücrelerinde elektriğe dönüştürmek için kullanılabilir hale getirmektedir [20].

(BREEAM- Building Research Establishment Environmental Assessment Method), İngiltere'de Yapı Araştırma Kurumu (BRE) tarafından geliştirilerek, 1990 yılında uygulamaya geçirilen Yapı Araştırma Kurumu Çevresel Değerlendirme Metodu yeşil bina değerleme sistemlerinin ilkidir. BREEAM sistemi, yönetim, sağlikta memnuniyet, enerji yönetimi, ulaşım, su, ve atık yönetimi, arazi kullanımı ve ekoloji, malzeme ve kirlilik gibi kriterler için puan toplayarak değerleme yapmaktadır [21].Sürdürülebilir kampüs olma yolunda Hollanda da Erasmus üniversitesi Breeam sertifika programını almaya hak kazanmıştır. Üniversite, 2005-2020 yıllar arasında dönemde \% 2'lik bir enerji tasarrufunu amaçlamakta, kağıt ve karton, cam, gres, yağ, yıkım atıkları, elektrikli aletler atıklarını ayırarak 2020 yılında kadar \% 75 oranında atık ayırma oranına ulaşmayı hedeflemektedir. Aynı zamanda güneş enerjisi sistemleriyle kendi elektriğini üretmektedir [22].

Tan vd. [23], Çin'de bulunan üniversitelerin yeşil ve sürdürülebilir kampüs uygulamalarına geçiş sürecinin 30 yıllık geçmişini değerlendirmiştir. Bu üniversiteler ilk aşamada, kampüsleri içerisinde tüketilen enerji miktarını gözlemlemiştir. 2011 yılında kapsamlı yeşil kampüs uygulaması için kapsamlı bir çalışma yapılarak gerekli strateji ve yönetmelikler geliştirilmiştir. Yeşil kampüs uygulamaları içinde "yeşil master 
planı", "çevreye duyarlı süreçler", "yeşil teknoloji”, "sosyal yardım” ve "yeşil eğitim" ana başlıkları yer almaktadır [23]. Tayland'da bulunan yeşil ve yeşil olmayan üniversite öğrencilerinin algısını ölçmek amacıyla bir anket düzenlenmiştir. Anket sonucunda öğrencilerin, yeşil kampüste yaşayan öğrencilerin yaşamayanlara göre daha iyi hizmet aldığ1 görülmüştür [24]. Malezya' da bulunan üniversitelerde sürdürülebilirliği değerlendirmeye yönelik bir anket düzenlenmiştir. $\mathrm{Bu}$ anket toplamda 10 farklı üniversitenin 14 farklı bölümünde okuyan öğrencilere uygulanmıştır [25]. Öğrencilerin \%62,6' sının, çalışanlarında \%51,6'sının üniversitelerin sürdürülebilirlik çalışmaları konusunda istekli olduğu görülmüştür. Litvanya üniversitesinde çevre, biyoloji ve fizik bölümüne kayıtlı öğrencilerin sürdürülebilir üniversite kampüsü algısını ölçmek amacıyla bir anket uygulamıştır. 2011-2012 yılları arasında uygulanan bu ankete göre çevre bölümünde okuyan öğrencilerin, diğer bölümlere göre sürdürülebilir ve ekolojik farkındalık konusunda daha duyarlı olduğu görülmüştür [26]. Fransa Lille kentinde bulunan Katolik üniversitesinde "ekonomik etkinlik", "çevreye duyarlılık", "sosyal eşitlik" başlıkları altında toplam 30 farklı kriterleri temel alıp sürdürülebilirlik üzerine bir değerlendirme yapılmıştır. Tüm kriterlerin etkinliklerini sürdürülebilir kampüs gösterge skoru ile değerlendirilmiştir. Buna göre; en önemli kriter ekonomik etkinlik olurken bunu "çevreye duyarlılık" ve "sosyal eşitlik" takip etmektedir [27]. Üniversite kampüslerinin sürdürülebilir fiziksel özelliklerini değerlendirmek amacıyla, sürdürülebilir kampüs indeksi geliştirmiştir. Bu indeks, "kentleşme", "yeşil kampüs" ve "kampüs içerisinde yaşam" olmak üzere üç başlık altında toplamda 10 sürdürülebilir gösterge kriterleri ile oluşturulmuştur. Çalışma sonucunda, tek yönlü- Anova ve PostHoc analizi yöntemleri kullanılarak, özel üniversitelerin sürdürülebilir kampüs uygulamaları açısından devlet üniversitelerine göre daha yüksek performansa sahip olduğu görülmüştür Tek yönlü Anova metodu ve Post - Hoc testi devlet ve özel üniversitelerinin fiziksel kalite skorlarının bağımsız ortalamaları arasındaki farkı test etmek amacıyla kullanılmıştır. Analiz sonuçlarına göre özel üniversiteler sürdürülebilirlik alanında, devlet üniversitelerinden daha yüksek kalite skoruna sahip çıkmıştır [28]. Japonya' da bulunan Osaka üniversitesinde sürdürülebilir kampüs uygulama çalışmalarına değinilmiştir. Üniversite tesisleri enerji kullanımına göre 3 kategoride değerlendirilmiştir. Bunlar içerisinde fotovoltaik sürdürülebilir enerji uygulamaları da mevcuttur. Osaka üniversitesi bu çalışmada enerji tasarrufunu \%22 oranında azaltmayı amaçlamıștır [29]. Mısır' da bulunan üniversitelerin kampüslerinin sürdürülebilir peyzaj açısından incelemiştir. Kahire'de bulunan üç üniversite kampüsünün toprak yapısı açısından farklılıkları değerlendirilmiştir [30]. Katar'ın batısında bulunan sürdürülebilir üniversite kampüs kalitesini SERVQUAL yöntemiyle değerlendirilmiştir. SERVQUAL yöntemi hizmet kalitesini ölçmek amaciyla Parasuraman ve ark. (1985) tarafından geliştirilen bir ölçme yöntemidir [31]. Bu yöntem, üniversitenin algılanan ve beklenen hizmet kalitesi arasındaki farklılığı ölçerek sürdürülebilir hizmet kalitesi ölçmüştür. Sonuçta öğrencilerin bekledikleri hizmet kalitesinin, algılanan hizmet kalitesinden düşük çıktığı görülmüş, algılanan ve beklenen arasındaki fark negatif çıkmıştır [32]. Sürdürülebilir kampüs uygulamaları kapsamında enerji tüketimini azaltmak için dinamik bir model geliştirilmiştir. Geliştirilen modelde, enerji ve maddi tasarruf olmak üzere iki performans kriteri, dört hipotez testi ile analiz edilmiştir [33]. Çin'de bulunan Shanghai üniversite kampüsünde, öğrencilerin karbon ayak izi ölçümü yapılmıştır. Öncelikli olarak öğrencilerin enerji tüketimi davranış ve tutumlarıyla ilgili bir anket uygulaması yapılmıştır. Sonuçta her öğrencinin ortalama karbon ayak izi yıllık 3,84 ton olarak çıkmış, bunun \% 65 günlük hareketlerinden, \% 20 ulaşımdan, \%15 de çalışırken göstermiş olduğu akademik aktivitelerden kaynaklandığ tespit edilmiştir [34]. 
Ülkemizde çevre duyarlılığı, enerji tasarrufu uygulamaları, ülke ekonomisine değer katmakla birlikte üniversite öğrencileri, akademisyenler ve idari çalışanlar olmak üzere mezunlarına da çevresel farkındalık konusunda katkı sağlamaktadır. $\mathrm{Bu}$ amaçla ülkemizde sürdürülebilir-ekolojik kampüs uygulamaları hızla yaygınlaşmaktadır. Sürdürülebilir kampüs kapsamında, üniversite kaynaklarını en ekonomik ve etkin bir şekilde değerlendirmeyi amaçlarken, bunların çevresel, ekonomik ve sosyal açıdan ortaya çıkacak olumsuz etkileri de en aza indirgenmesi sağlanmaktadır. Sürdürülebilir kampüs uygulamaları ülkemizde oldukça yeni olup 7 yıllık bir geçmişi vardır. Türkiye'de ilk yeşil üniversite binasına sahip Boğaziçi Üniversitesi, sürdürülebilir kampüs uygulamasına 2011 yılında kampüste karbon ayak izi ölçümleriyle başlamıştır. Bu çalışmanın devamı olarak su, enerji, atık yönetimi konusunda veriler toplanmış ve raporlama yapılarak çevresel performans değerlendirmesi ortaya koyulmuştur.

\section{Materyal ve yöntem}

$\mathrm{Bu}$ çalışmada, uluslararası düzeyde sürdürülebilir çalışmalarını değerlendiren UI Greemetric sıralaması baz alınarak ülkemizde sıralamaya giren üniversiteler değerlendirilmiştir. Bu üniversitelerin, Enerji yönetimi, atık yönetimi, eğitim yönetimi, ulaşım yönetimi, çevre ve peyzaj uygulamaları ve su yönetimi programları çerçevesinde üniversitelerin mevcut durumları incelenmiştir. Bu aşamada yer alan göstergeler konu ile ilgili anket çalışmaları, UI Greenmetric sıralama tablosu ve üniversitelerin web sayfalarından yararlanılmıştır. UI Greenmetric sıralamada kullanılan kategoriler; "yapı ve altyapı", "enerji ve iklim değişiklikleri", "atıklar", "su”, "ulaşım" ve "eğitim" modifiye edilerek ülkemizin üniversite kampüs imkânlarına uygun olacak şekilde revize edilmiştir [35].

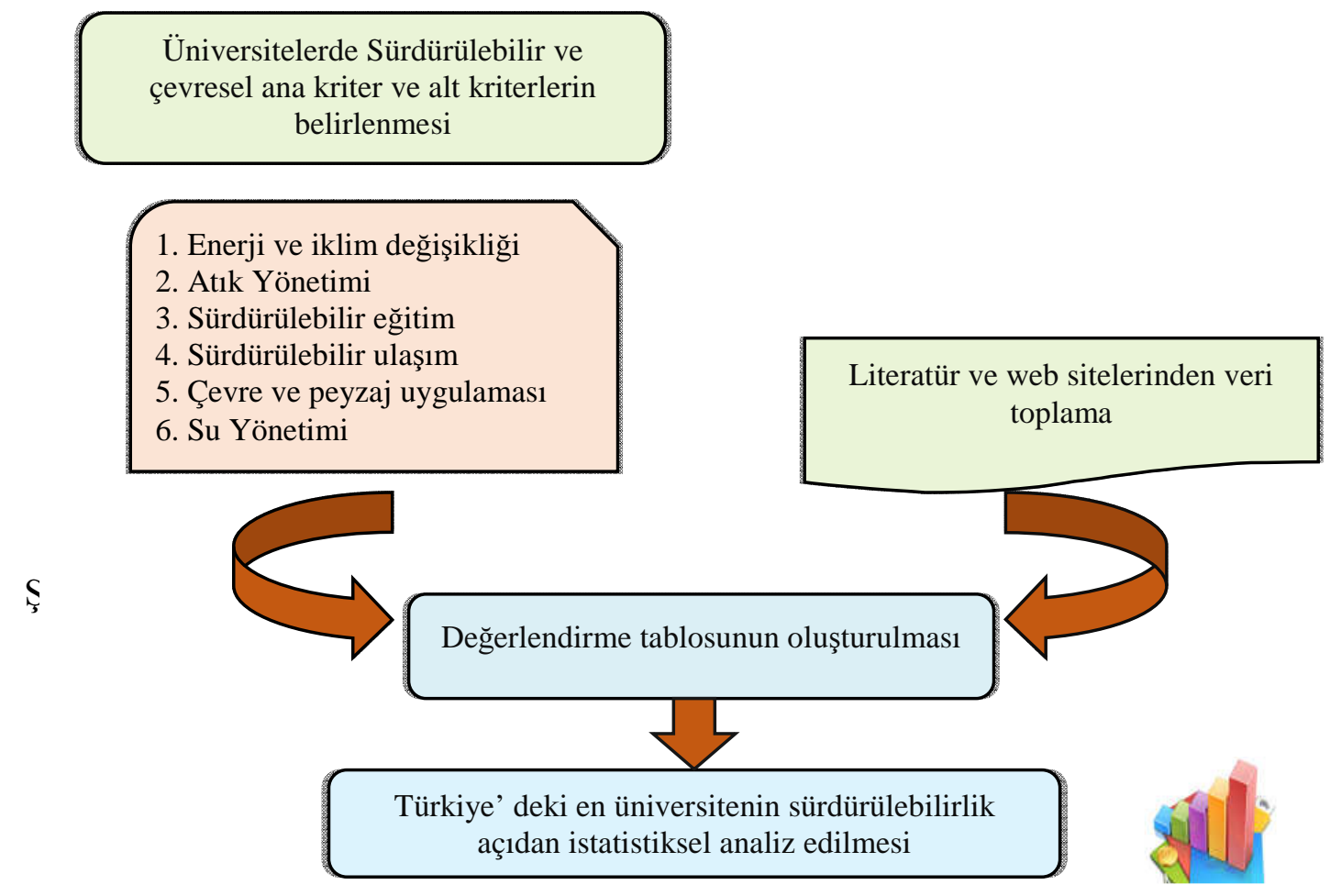

Şekil 1. Çalışma yönteminin şematik gösterimi. 


\section{Türkiye'deki sürdürülebilir-ekolojik üniversite kampüslerinin değerlendirilmesi}

Türkiye'de sürdürülebilir kampüs uygulamaları oldukça yenidir. Bu kapsamda öncelikli olarak Greenmetric kriterleri baz alınarak, sürdürülebilir kampüs uygulamalarına başlanmıştır. Daha sonraları sürdürülebilir kampüs uygulamaları Sabancı ve Bilkent olmak üzere iki vakıf üniversitesinde 2011-2012 yılları arasında Greenmetric sıralamasında Sabancı Üniversitesi ve Bilkent üniversitesi olmak üzere iki vakıf üniversitesi ilk 200. sırada yer almıştır. Sabancı üniversitesi sürdürülebilir ve ekolojik kampüs uygulaması çerçevesinde yoğunluklu olarak "Çevre ve peyzaj uygulamaları" ve “sürdürülebilir ulaşım” kriterlerine önem vermiştir. Bu kapsamda kampüs içini 100’ den fazla farklı endemik tür bitki ile zenginleştirerek ve peyzaj düzenlemeleri yaparak yeşil ve ekolojik kampüs olma yolunda ilerlemiştir [36]. Üniversite kampüs içerisinde kullanılmak üzere elektrikli araç şarj istasyonu kurdurmuştur, bu sayede kampüs içinde çevreye dost, hava kirliliğini azaltan elektrikli araçların kullanımını yaygınlaştırmayı amaçlamıştır [35]. Bilkent üniversitesi, sürdürülebilir ve ekolojik kampüs olma yolunda kampüsünün yaklaşık \%60’ı ağaçlandırılmıştır [38].

Ülkemizde yükseköğretim kurumları özel ve devlet üniversitesi olmak üzere ikiye ayrılmıştır. Vakıf üniversiteleri kurucu vakıf bütçesi, öğrenci harç ücretleri ve proje gelirleri ile finansmanını sağlamaktadır. Vakıf üniversiteler, devlet üniversitelerine kıyasla öğrenci çekmek için başta eğitim-öğretim kalitesi başta olmak üzere kampüs için hizmet kalitesini de iyileştirmek istemektedir. Vakıf üniversiteleri sürdürülebilirlik ve çevre bilinci konusunda devlet üniversiteleriyle rekabet halindedir. Buradan yola çıkarak vakıf ile kamu üniversiteleri arasında sürdürülebilir kalite boyutunda bir farklılık olup olmadığı incelenmiştir. Bu amaçla 5 devlet ve 5 vakıf üniversitesi olmak üzere toplam 10 üniversite kampüsü sürdürülebilir-ekolojik kriterler baz alınarak değerlendirilmiş ve seçilen üniversiteler Tablo 1'de gösterilmiştir.

Enerji ve iklim değişiklikleri, atık değerlendirme, su yönetimi, sürdürülebilir ulaşım, sürdürülebilir eğitim ve kampüs içi yeşillendirme olmak üzere 6 ana kriter ve her birinin kendi içinde alt kriterleri olmak üzere toplam 29 alt kriter üzerinden değerlendirmeler yapılmıştır. Enerji ve iklim değişiklikleri kriterleri altında, son yıllarda büyük önem kazanan ve uygulama alanı artış gösteren yeşil bina uygulamaları, yenilenebilir enerji uygulamaları (güneş, biyogaz vb.), bina enerji yönetimi ve uygulamaları yer almaktadır. Su yönetimi, yağmur ve gri suyun geri kazanımı, sus koruma planının oluşturulması, damla ve otomatik sulama hizmetlerinin geliştirilmesi alt başlıklarında değerlendirilmiştir. Yağmur ve gri su geri kazanımı ile, kampüs içinde tüketilecek su miktarı büyük oranda azaltılabilmektedir. Kampüs içerisinin damla ve otomatik sulama ile yapılması, yüzey akışı ve buharlaşmadan kaynaklı su kaybını azaltarak su tasarrufunu sağlamaktadır.

Sürdürülebilir ulaşım; çevreye duyarlı, $\mathrm{CO}_{2}$ emisyon miktarını minimize eden, araçların kampüs içi ulaşımda yaygınlaştırılması ile gerçekleşmektedir. Kampüs içinde bisiklet evlerinin kurulması, elektrikli ve hibrit taşıma araçlarının yaygınlaştırılması ve toplu taşımaya yönlendirilme, sürdürülebilir ulaşım içerinde yer almaktadır.

Çevreye duyarlı nesiller yetiştirmek sürdürülebilir eğitimle gerçekleşmektedir. Üniversitede çevre bilincini aşlayan derslerin verilmesi, seminer ve programların düzenlenmesi, sosyal sorumluluk projeleri ve klub etkinlikleri ile öğrencilere çevre sorunlarıyla yüzleşmesini sağlamayı amaçlar.

Sürdürülebilir kampüs yaşamı ilkesiyle, doğal varlıkların korunması için kampüs içi ağaçlandırma çalışmalarıyla yapılmaktadır. Ağaçlandırma başta erozyon ve çölleşmeden 
kaynaklı oluşabilecek toprak kaybını azaltırken, bulundukları yerin havasını da temizlemektedir.

Tablo 2'de, yer alan mevcut kriterler 10 üniversite için incelenmiştir. Seçilen üniversiteler ülkemizde evreye duyarlı ve sürdürülebilir kampüs olma yolunda çaba gösteren UI Greenmetric sıralamasında devlet ve vakıf üniversiteleri içinde ilk 500' e giren üniversiteler içinden seçilmiştir. Betimleyici ve durum saptayıcı bir analiz yöntemi kullanılarak, kriterler mevcut / mevcut değil şeklinde değerlendirilmiştir. Buna göre; devlet üniversiteleri arasında Boğaziçi Üniversitesi, vakıf üniversiteleri arasında Bilgi Üniversitesi sürdürülebilir-ekolojik kampus olma seviyesi açısından en yüksek puanı almışlardır. Yine Tablo 2'den anlaşılacağı üzere devlet üniversiteleri, özel üniversitelere göre sürdürülebilirlik konusunda daha duyarlı olduğu tespit edilmiştir.

Tablo 1. Sürdürülebilir-ekolojik kampüs açısından değerlendirilen devlet ve vakıf üniversiteleri.

\begin{tabular}{ll}
\hline Devlet Üniversiteleri & Vakıf Üniversiteleri \\
\hline Boğaziçi Üniversitesi & Özyeğin Üniversitesi \\
Bülent Ecevit Üniversitesi & Yeditepe Üniversitesi \\
Karabük Üniversitesi & Bahçeşehir Üniversitesi \\
İstanbul Teknik Üniversitesi & Bilgi Üniversitesi \\
Ege Üniversitesi & Bilkent Üniversitesi \\
\hline
\end{tabular}


Tablo 2. Sürdürülebilir-ekolojik duyarlılık açısından Türkiye'deki 5 devlet ve 5 vakıf üniversite kampüslerinin değerlendirilmesi.

\begin{tabular}{|c|c|c|c|c|c|c|c|c|c|c|}
\hline & \multicolumn{5}{|c|}{ Devlet Üniversiteleri } & \multicolumn{5}{|c|}{ Vakıf Üniversiteleri } \\
\hline & Boğaziçi & Bülent Ecevit & Ege & Karabük & İTÜ & Bahçeşehir & Bilgi & Bilkent & Özye ğin & Yeditepe \\
\hline \multicolumn{11}{|l|}{ Enerji ve İklim Değişiklikleri } \\
\hline Yeşil bina uygulaması & $\checkmark$ & & & & & & $\checkmark$ & & $\checkmark$ & \\
\hline Kampüs içinde güneş panellerinin bulunması & $\checkmark$ & & & & & & & & & $\checkmark$ \\
\hline LED aydınlatma sisteminin bulunması & $\checkmark$ & $\checkmark$ & $\checkmark$ & $\checkmark$ & $\checkmark$ & $\checkmark$ & $\checkmark$ & $\checkmark$ & $\checkmark$ & $\checkmark$ \\
\hline Rüzgar enerjisi terminallerinin bulunması & $\checkmark$ & & $\checkmark$ & & & & & & & \\
\hline Biyogaz enerjisi & & & & $\checkmark$ & & & & & & \\
\hline Bina yaltımının yapılmış olması & $\checkmark$ & $\checkmark$ & $\checkmark$ & $\checkmark$ & $\checkmark$ & $\checkmark$ & $\checkmark$ & $\checkmark$ & $\checkmark$ & $\checkmark$ \\
\hline \multicolumn{11}{|l|}{ Attk Değerlendirme } \\
\hline Geri dönüşüm kutularının bulunması & $\checkmark$ & $\checkmark$ & $\checkmark$ & $\checkmark$ & $\checkmark$ & $\checkmark$ & $\checkmark$ & $\checkmark$ & $\checkmark$ & $\checkmark$ \\
\hline Atık su değerlendirme programının bulunması & $\checkmark$ & $\checkmark$ & $\checkmark$ & & $\checkmark$ & $\checkmark$ & $\checkmark$ & $\checkmark$ & $\checkmark$ & $\checkmark$ \\
\hline Kendine ait bir geri dönüşüm tesisinin olması & $\checkmark$ & $\checkmark$ & $\checkmark$ & & & & $\checkmark$ & & & $\checkmark$ \\
\hline Tehlikeli atıklarının geri dönüşümün düzenlenmesi & $\checkmark$ & $\checkmark$ & $\checkmark$ & & & & $\checkmark$ & & & $\checkmark$ \\
\hline Kâğıt ve plastik kullanımın azaltılmasına yönelik teşvik ve uygulamalar & $\checkmark$ & $\checkmark$ & & & $\checkmark$ & & & & & \\
\hline Elektronik atkların toplanıp tekrardan değerlendirilmesi & $\checkmark$ & $\checkmark$ & & & & & & & & \\
\hline \multicolumn{11}{|l|}{ Su Yönetimi } \\
\hline Yağmur suyunun geri kazanımı & $\checkmark$ & $\checkmark$ & & & $\checkmark$ & & & $\checkmark$ & $\checkmark$ & \\
\hline Sensörlü musluk ve lavabolarnn bulunması & & $\checkmark$ & & & $\checkmark$ & & $\checkmark$ & $\checkmark$ & & \\
\hline Su korunum programının geliştirilmesi & $\checkmark$ & $\checkmark$ & $\checkmark$ & $\checkmark$ & $\checkmark$ & $\checkmark$ & $\checkmark$ & $\checkmark$ & $\checkmark$ & $\checkmark$ \\
\hline Damla sulama ya da otomatik sulama sistemi & & & & & & & & $\checkmark$ & & $\checkmark$ \\
\hline \multicolumn{11}{|l|}{ Sürdürülebilir Ulaşım } \\
\hline Bisiklet evlerinin kurulması & $\checkmark$ & $\checkmark$ & & $\checkmark$ & $\checkmark$ & & & & & \\
\hline Özel araç sayısını azaltılmasına yönelik çalışmalar & & $\checkmark$ & & $\checkmark$ & $\checkmark$ & & & $\checkmark$ & $\checkmark$ & \\
\hline \multicolumn{11}{|l|}{ Kampüs için ulaşımın elektrikli araçlarla yapılması } \\
\hline \multirow{2}{*}{\multicolumn{11}{|c|}{$\begin{array}{l}\text { Park alanlarmı sinirlandirma politikasinin uygulanması } \\
\text { Sürdürülebilir Eğitim }\end{array}$}} \\
\hline & & & & & & & & & & \\
\hline Çevre ve doğa korunumuyla ilişkili derslerin verilmesi & $\checkmark$ & $\checkmark$ & $\checkmark$ & $\checkmark$ & $\checkmark$ & $\checkmark$ & $\checkmark$ & $\checkmark$ & $\checkmark$ & $\checkmark$ \\
\hline Sosyal sorumluluk klüblerinin bulunması & $\checkmark$ & $\checkmark$ & $\checkmark$ & $\checkmark$ & $\checkmark$ & $\checkmark$ & $\checkmark$ & $\checkmark$ & $\checkmark$ & $\checkmark$ \\
\hline Çevre konulu kongre, toplantı ve seminerlerin düzenlenmesi & $\checkmark$ & $\checkmark$ & $\checkmark$ & $\checkmark$ & $\checkmark$ & $\checkmark$ & $\checkmark$ & & & \\
\hline Web sitesinde sürdürülebilirlik üzerine tanttmlar yapılması & $\checkmark$ & $\checkmark$ & $\checkmark$ & $\checkmark$ & $\checkmark$ & & $\checkmark$ & $\checkmark$ & & $\checkmark$ \\
\hline TEMA vb. iş birliği çalışmaları & $\checkmark$ & $\checkmark$ & $\checkmark$ & $\checkmark$ & & & & & $\checkmark$ & \\
\hline \multicolumn{11}{|l|}{ Kampüs içi Çevre ve Peyzaj Yönetimi } \\
\hline Üniversitenin yeşil alana sahip olması & $\checkmark$ & $\checkmark$ & $\checkmark$ & $\checkmark$ & $\checkmark$ & $\checkmark$ & $\checkmark$ & $\checkmark$ & $\checkmark$ & $\checkmark$ \\
\hline Endemik bitki ve hayvanlar için koruma alanına sahip olması & $\checkmark$ & $\checkmark$ & $\checkmark$ & $\checkmark$ & $\checkmark$ & $\checkmark$ & $\checkmark$ & $\checkmark$ & $\checkmark$ & $\checkmark$ \\
\hline Sürdürülebilir peyzaj çalışmalarının yapılması & $\checkmark$ & $\checkmark$ & $\checkmark$ & $\checkmark$ & $\checkmark$ & $\checkmark$ & $\checkmark$ & $\checkmark$ & $\checkmark$ & $\checkmark$ \\
\hline Yeşil çatı sisteminin kurulması & & & & & & & & & $\checkmark$ & \\
\hline Sonuç & 22 & 22 & 16 & 15 & 17 & 11 & 16 & 15 & 15 & 15 \\
\hline
\end{tabular}


Sürdürülebilir-ekolojik kampüs için belirlenen ana kriterler Şekil 2'de gösterilmiştir. Boğaziçi Üniversitesi, enerji ve iklim değişikliğine yönelik çalışmalarının başında "yeşil bina" ve "yenilenebilir enerji" uygulamaları olduğu görülmektedir. Şekil 3'e göre Boğaziçi Üniversite kampüsü açık ara farkla "enerji ve iklim değișikliğinde" diğer üniversitelerin önündedir. Boğaziçi Üniversitesi farkındalık yaratmak için LEED "GOLD” sertifikasına sahip ilk yeşil üniversite Hamlin Hall (erkek yurdu) binasının restorasyonunu yapmıştır. Yeşil bina çalışmasında, karbon ve su ayak izi ölçmüş atık verileri ve atık miktarlarını günlük kayıt altına alınmıştır. Karbon ayak izi, bina içinde tüketilen başta elektrik, fosil yakıtlar kaynaklı olmak üzere, kişilerin kullandıkları ürünlerin tüm yaşam döngüsü sürecinde ortaya çıkan $\mathrm{CO}_{2}$ emisyon ölçüsüdür. Binalarda karbon salınımının en büyük kaynağı 1sıtma ve soğutma için tüketilen enerjidir. Karbon ayak izinin artışı, başta küresel ısınma ve iklim değişikliği olmak üzere birçok çevre sorununu beraberinde getirmektedir. Küresel ısınma ile birlikte yaşanan iklim değişiklikleri, başta kutuplar olmak üzere dünya genelinde bir çok coğrafyayı etkisi altına almaktadır. Yeryüzü sıcaklığının artması kutuplardaki buzulların erimesine, buna bağlı olarak deniz seviyesinde olan bir çok ülkenin sular altında kalmasına neden olacaktır. Küresel ısınma arttıkça, dünyanın bazı bölgelerinde şiddetli kasırga ve seller olurken bazı bölgelerde verimli arazilerin kuraklaşma ve çölleşme görülecektir [39]. Çevreye duyarlı ve karbon ayak izini minimize edecek şekilde tasarlanan Hamlin Hall binası güneş kolektörü su 1sıtma sistemi ve led aydınlatma sistemi kullanarak karbon ayak izini azaltmayı amaçlamıştır. Yeşil bina aynı zamanda banyo lavabolarında ve çamaşır makinalarında ortaya çıkan atık suları bir diğer adıyla Gri suları arıtarak, doğrudan bahçe sulamasında kullanmaktadır. Gri su geri kazanım sistemi, binada doğal su kaynaklarının gereksiz kullanımını azaltarak, çevre korunmasına katkı sağlamakta aynı zamanda su arıtımı için gerekli olan enerji miktarını \% 25 oranında düşürmektedir [19]. Türkiye de ilk kez uygulanan üniversite kampüsü bina örneği Şekil 4'de gösterilmiştir.

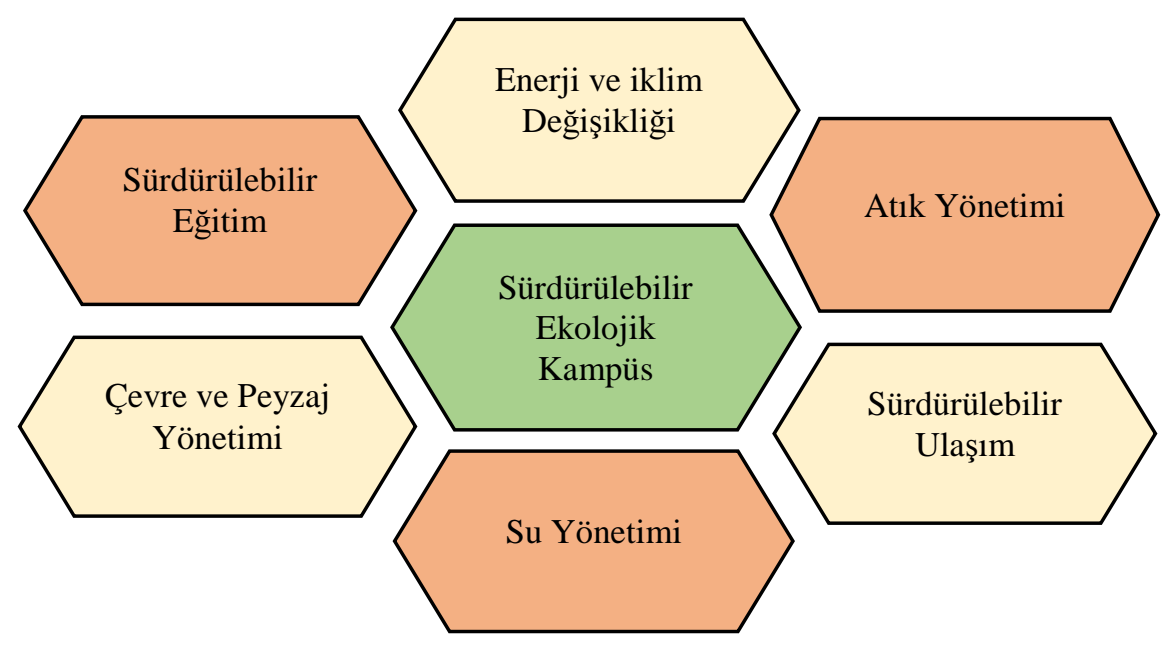

Şekil 2. Sürdürülebilir-ekolojik üniversite kampüslerinin ana kriterleri. 


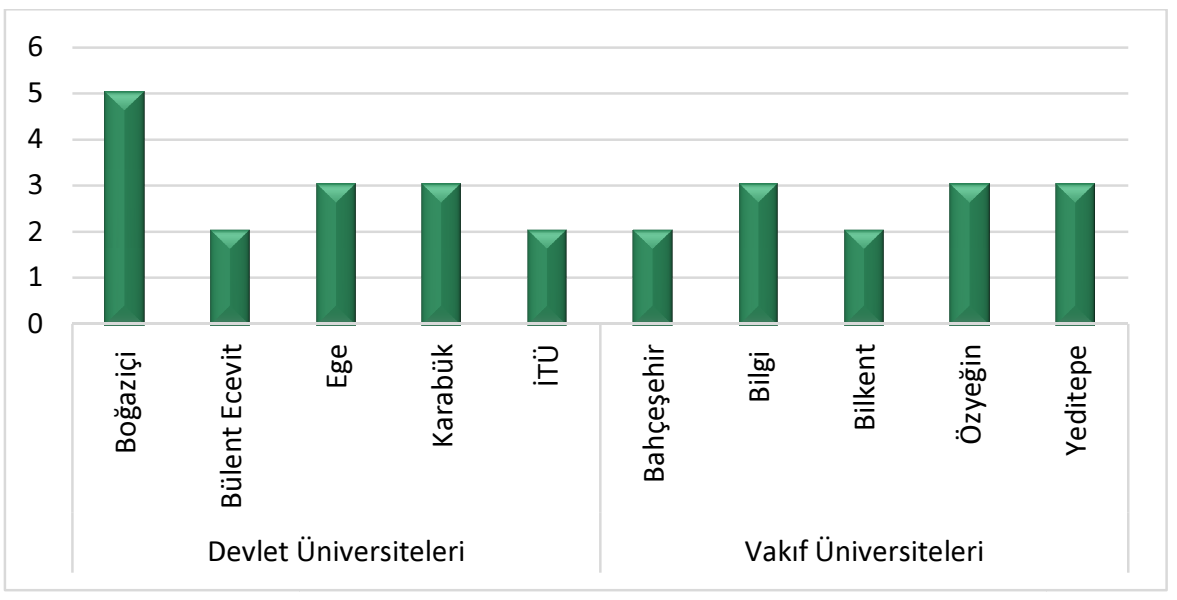

Şekil 3. Devlet ve vakıf üniversitelerinin enerji ve iklim değişikliği açısından değerlendirilmesi.

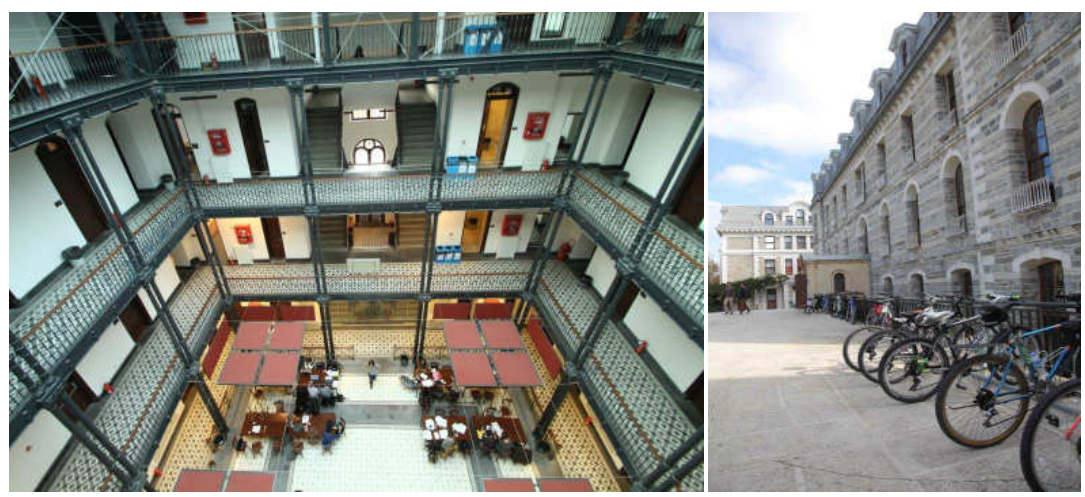

Şekil 4. Boğaziçi üniversitesi yeşil bina örneği [19].

Enerji ve iklim değişikliği ana bağlığı altında; yenilenebilir enerji uygulamaları (güneş panelleri, rüzgâr enerji vb.), elektrik enerjisinden kaynaklı Led aydınlatmalı ve enerji tasarruflu lambaların $\left(\mathrm{A}^{++}\right)$kullanılması, 1sı ve enerji tasarrufu amaçlı binaların yalıtımının yapılması, kampüs içinde örnek yeşil bina bulunup bulunmaması gibi alt kriterler bulunmaktadır. Yenilenebilir enerji uygulamalarında Boğaziçi ve Yeditepe üniversitesi, kampüs içi güneş panellerinden faydalanarak, elektrik ihtiyaçlarının bir kısmını buradan sağlamaktadır (Şekil 5).

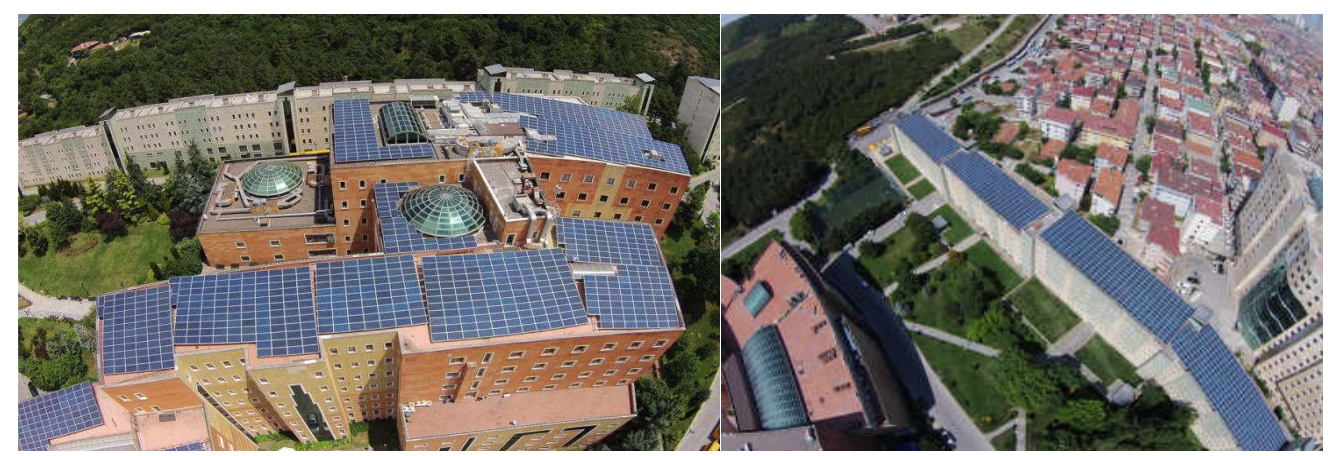

Şekil 5. Yeditepe üniversitesi güneş panelleri. 
Atık yönetimi ana başlığı altında; atıkların geri dönüşümü, katı ve sıvı atıkların tekrar kullanımı, teşvik ve uygulama yöntemleri yer almaktadır. Su kullanımı ana başlığı altında; gri yağmur suyu uygulamaları, su kullanımını azaltıcı politikaların vb. uygulamalar değerlendirilebilmektedir. Sürdürülebilir ulaşım ana başlığında; kampüs içinde karbon emisyonunu azaltıcı politikalara yer verilmiştir. Sürdürülebilir eğitim kriteri içerisinde; üniversite öğrencilerinin ve çalışanların çevre ve doğaya karşı sorumlulukları, çevre kulüplerinin varlığı, doğa turlarının yapılması, kongre ve etkinliklerinin sürdürülebilir olması vb. alt kriterler bulunmaktadır. Kampüs içinin yeşillendirilmesi; ekolojik bir kampüs için olmazsa olmaz şartlardan bir tanesidir. Kampüsün içinin yeşillendirilmesi, endemik bitki ve hayvan türlerinin bulunması, peyzaj uygulamaları ve çevre düzenlemeleri bu kapsamda değerlendirilmektedir.

Atık yönetimi açısından en iyi üniversiteler devlet üniversiteleridir, ilk iki sırada Boğaziçi ve Bülent Ecevit Üniversiteleri yer almaktadır (Şekil 6). Bütün üniversitelerde geri dönüşüm kutularının bulunmasına rağmen çok azında geri dönüşüm tesisi mevcuttur. Kâğıt, plastik ve elektronik atıkların geri kazanımına yönelik teşvik edici çalışmalar oldukça yetersizdir. Şekil 7'de "Su Yönetimi” üzerine yapılmış olan çalışmalarda, Karabük Üniversitesinin su koruma programı olmadığ1 görülmüştür. Bilkent Üniversitesi, su koruma programı açısından en gelişmiş üniversite olup damla ve otomatik sulama sistemine sahip tek üniversite konumundadır. Sürdürülebilir-ekolojik üniversite kampüsü olma yolunda en önemli girdilerden biride çevre ve insan sağlığını tehdit eden ve küresel 1sınmayı tetikleyen ulaşım kaynaklı emisyonların azaltılması ve yaşam kalitesinin arttırılmasıdır. Bu doğrultuda kampüs içi ulaşım sorunlarına sürdürülebilir çözümler geliştirmeye ve insan odaklı ulaşım proje ve politikaları geliştirilmeye çalışılmaktadır. Sürdürülebilir-ekolojik kampüs, çevreye zararlı motorlu taşıma araçlarının azaltılıp yerine çevre dostu ulaşım araçlarının (elektrikli otobüs, güneş enerjili arabalar vb.) kullanılması ve yayalaştırma politikasının geliştirilmesi üzerinedir. İTÜ Ayazağa kampüsünün kampüsün her yanına bisiklet yolları yaparak, temiz, çevreye uyumlu sürdürülebilir bir ulaşım imkânı hazırlamıştır (Şekil 10). Bisiklet kullanımını artırarak, kampüs için hava kalitesini artırmayı ve karbon ayak izini azaltmayı hedeflemektedir. Şekil 8'e göre devlet üniversiteleri içinde Ege Üniversitesi, özel üniversitelerde ise Bahçeşehir, Bilgi ve Yeditepe Üniversiteleri "Sürdürülebilir ulaşım" yönünden hiçbir katkıda bulunmamışlardır. Bülent Ecevit Üniversitesi özellikle sürdürülebilir ulaşımda öncü rolü üstlenmekte, bu amaçla kampüs içinde yaya alanlarını arttırma ve araç kullanımını azaltma politikaları uygulanmış ve kampüsünün büyük kısmı yayalaştırılmıştır (Şekil 9). Tablo 2 de verilen analiz sonuçları alt kriterler altında sayısallaştırılarak sırasıyla Şekil 3, Şekil 6, Şekil 7, Şekil 8, Şekil 11, Şekil 12 de gösterilmiştir.

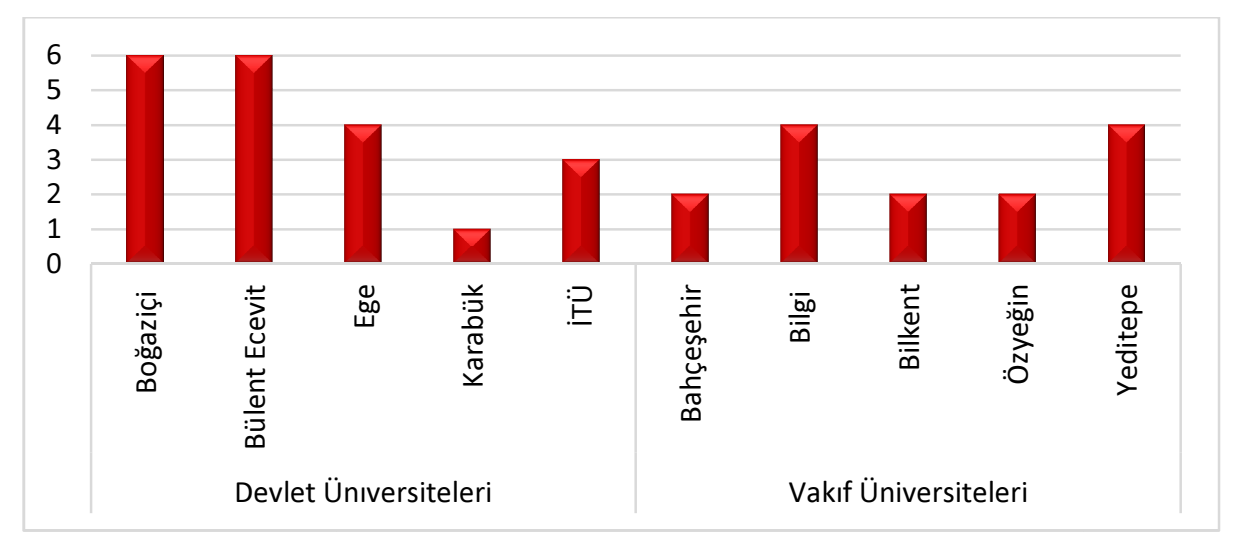

Şekil 6. Devlet ve vakıf üniversitelerinin “atık yönetimi” açısından değerlendirilmesi. 


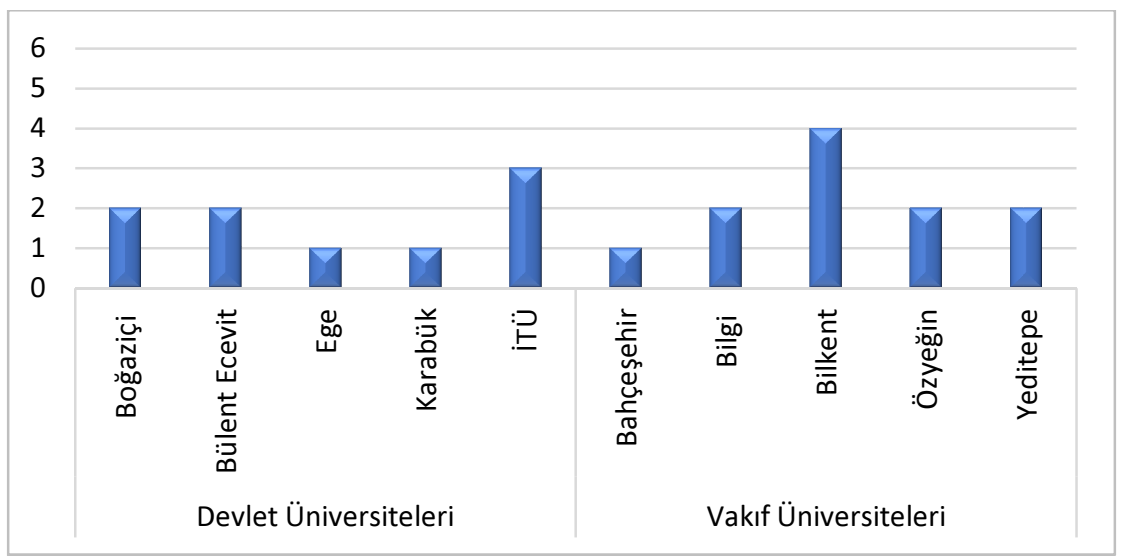

Şekil 7. Devlet ve vakıf üniversitelerinin "su yönetimi”" açısından değerlendirilmesi.

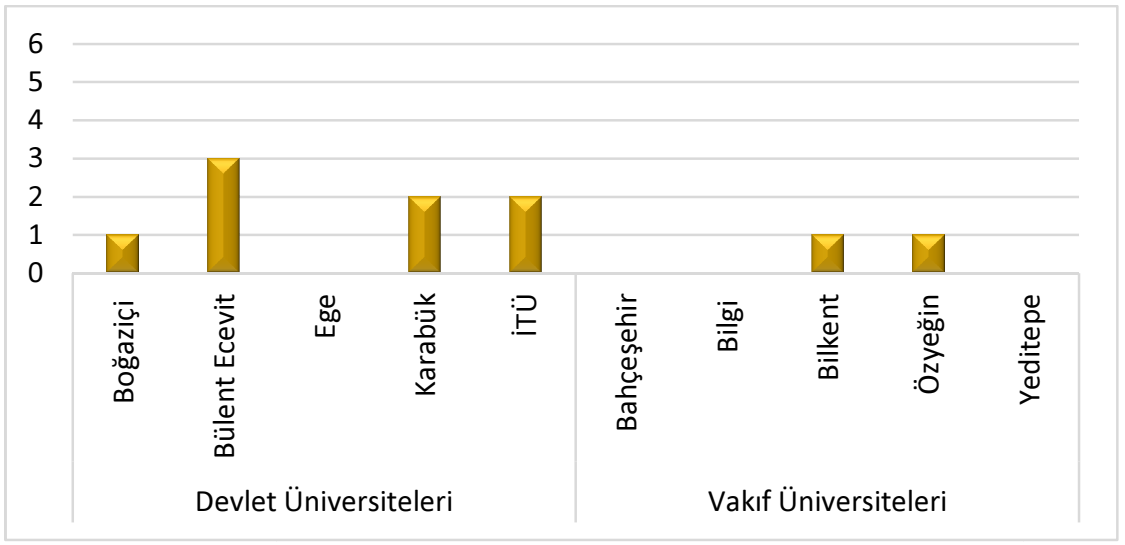

Şekil 8. Devlet ve Vakıf Üniversitelerinin "sürdürülebilir ulaşım” açısından değerlendirilmesi.

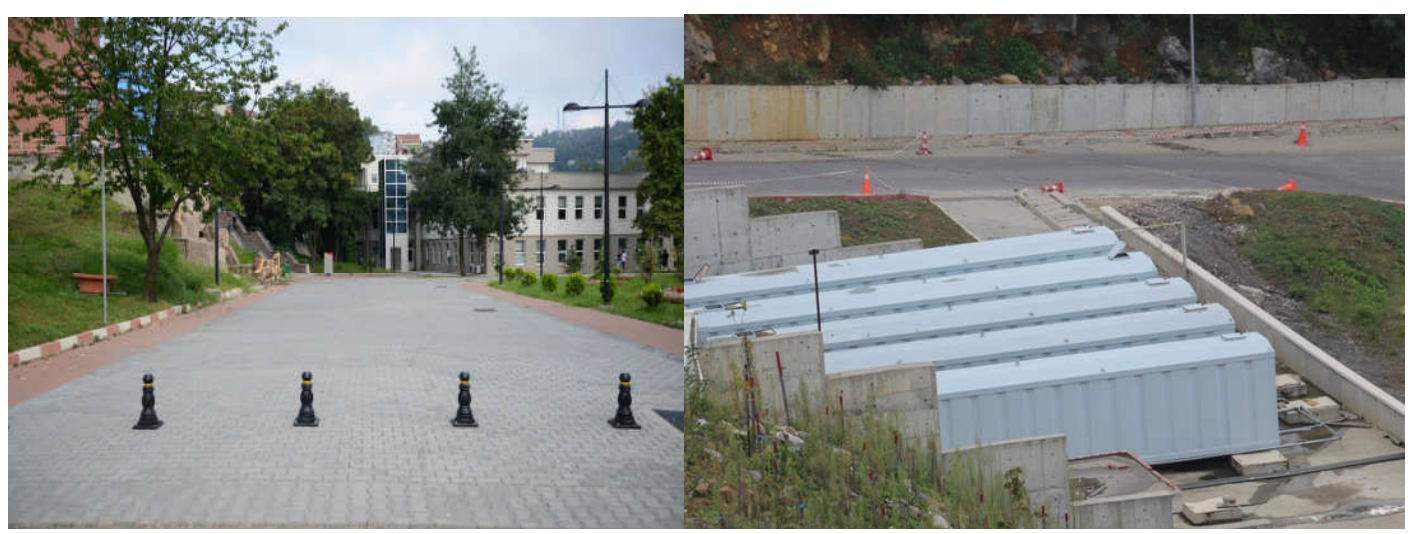

Şekil 9. Bülent Ecevit Üniversite kampüsünde yayalandırma ve atık yönetimi. 


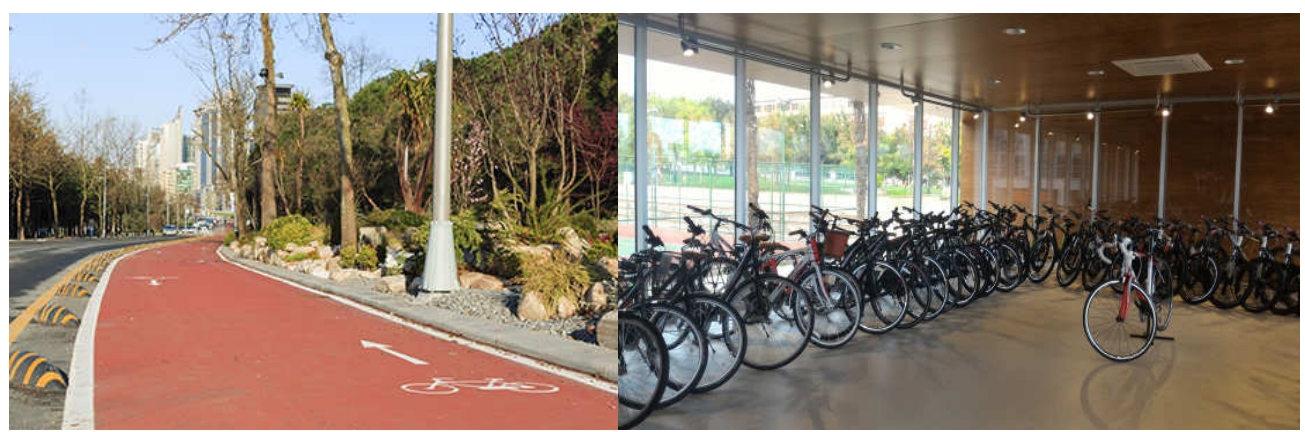

Şekil 10. İTÜ Ayazağa kampüsü bisiklet yolu ve bisiklet evi.

"Sürdürülebilir Eğitim" politikasında hemen her üniversite eşit katkıda bulunmasına rağmen, devlet üniversiteleri, özel üniversitelere kıyasla ileri seviyededir (Şekil 11). Boğaziçi, Bülent Ecevit, Ege ve Karabük Üniversiteleri hem öğrencilerine hem de akademiye katkı sağlamak için çevre ve ekolojik dengenin korunmasıyla ilgili lisans ve lisansüstü programlar açmışlardır. Bülent Ecevit Üniversitesi Alternatif Üniversite toplulukları altında; bisiklet, çevre, genç tema, doğa ve kültür kulübü, yeşil kimya ve çevre, gezi kulüpleri açarak öğrencilerini çevre korunmasına teşvikte bulunmuşlardır [40]. Boğaziçi Üniversitesi Türkiye Erozyonla Mücadele, Ağaçlandırma ve Doğal Varlıkları Koruma Vakfı (TEMA) iş birliği kurarak, kampüs hayatını yeşillendirmek ve ekolojik hale getirmek için farklı türlerden 60 bin ağaç dikilmesini ve endemik türlerin koruma altına alınmasını sağlamıştır [19].

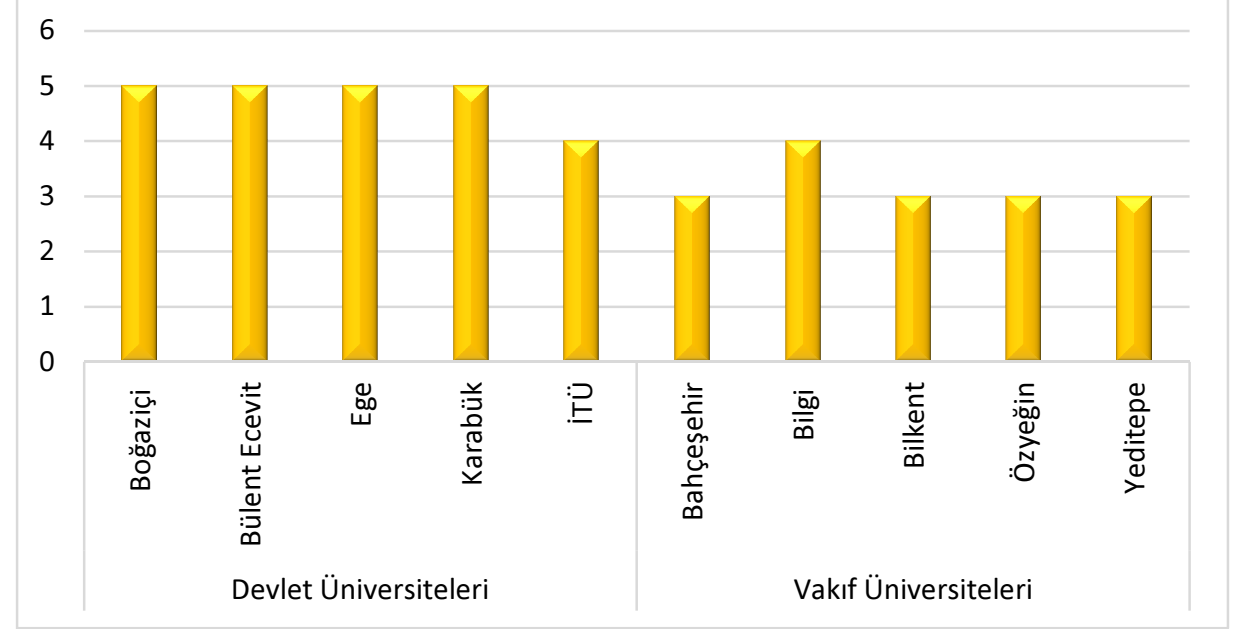

Şekil 11. Devlet ve Vakıf Üniversitelerinin “sürdürülebilir eğitim” açısından değerlendirilmesi.

Mevcut üniversitelerin hemen hepsi yeşil alanlarının arttırılması ve sürdürülebilir peyzaj çalışmalarına büyük önem vermiştir. Ancak bu durum, üniversite kampüslerinde yeşil çatı sisteminin kurulmasında yetersiz kalmıştır. Yeşil çatı bir diğer adıyla ekolojik çatı uygulaması ile hem bitki çeşitliliği sağlanmış hem de iyi bir ısı yalıtımı oluşturulmuştur (Şekil 12). 


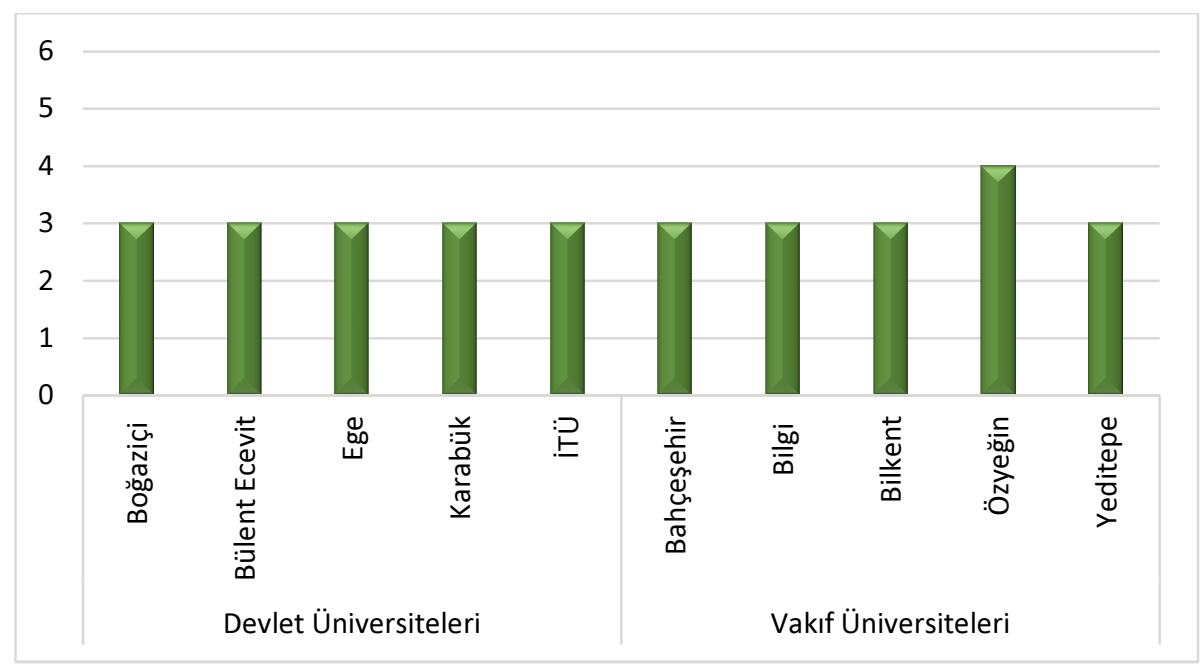

Şekil 12. Devlet ve Vakıf Üniversitelerinin “çevre ve peyzaj” açısından değerlendirilmesi

\section{Sonuçlar ve öneriler}

Üniversitenin temel misyonu, eğitim ve öğretim olmakla birlikte, bu yükseköğretim kurumları, içinde bulundukları bölgelerin nüfusuna, çevre ve kentsel sorunlarında çok değerli katkılar yapabilmektedir. Üniversiteler; kendi faaliyetlerini gerçekleştirirken insan kaynaklı çevresel faktörleri en aza indirgemek için çalışan ve topluma sürdürülebilir bir yaşam biçimi konusunda öncülük eden yükseköğrenim kurumlarıdır.

$\mathrm{Bu}$ çalışmada, Türkiye'deki sürdürülebilir-ekolojik konusunda iyi konumda bulunan 10 üniversite kampüsü değerlendirmiştir. Üniversitelerin sürdürülebilir-ekolojik kampüs parametreleri sırasıyla "enerji ve iklim değişikliğiı", "atık yönetimi”, "sürdürülebilir ulaşım", "su yönetimi”, “çevre ve peyzaj yönetimi”, "sürdürülebilir eğitim” olmak üzere 6 kategoride incelenmiş ve istatistiksel değerlendirilmesi yapılmıştır. "Enerji ve iklim değişikliği" açısından devlet üniversiteleri kampüsleri karşılaştığında Boğaziçi kampüsü iyi durumdayken, Bülent Ecevit Üniversitesi ve İTÜ daha alt seviyede kaldığı görülmüştür. Vakıf üniversiteleri enerji ve iklim değişikliği konularında yetersiz olduğu ve azami seviyeye ulaşamadığı görülmüştür. Atık yönetimi konusunda, devlet üniversiteleri içerinde Boğaziçi ve Bülent Ecevit Üniversitesi iyi durumdayken, Karabük Üniversitesi daha düşük durumdadır. Vakıf üniversiteleri arasında Bilgi Üniversitesi ve Yeditepe Üniversiteleri öncü rol oynarken, devlet üniversitelerine göre kıyaslandığında vakıf üniversiteleri daha düşük puanlara sahip olduğu görülmüştür. Su yönetiminde, devlet üniversiteleri arasında İTÜ; vakıf üniversiteleri arasında ise Bilkent Üniversitesi yüksek puana sahip üniversitelerdendir.

Devlet üniversiteleri içinde Bülent Ecevit Üniversitesi, vakıf üniversiteleri içinde Bilkent ve Özyeğin Üniversitesi, sürdürülebilir ulaşım kapsamında en iyi üniversitelerdir. Bilgi Üniversitesi, Bahçeşehir Üniversitesi ve Yeditepe Üniversitesinin özel araç sayısını azaltmaya, park yeri kısıtlamaya yönelik yeterli çalışmalarının olmadığı görülmüştür. Ayrıca tüm üniversiteler kampüs içerisinde elektrikli ulaşım araçlarını kullanımına yönelik bir çalışmada bulunmamıştır. Sürdürülebilir ulaşım imkanları açısından üniversitelerin yeterli durumda olmadığ görülmüştür. 
Sürdürülebilir eğitim uygulamaları yönünden neredeyse tüm üniversiteler eșit önem derecelerine sahiptir, bu kapsamda çevre ve doğa korunumuyla ilgili dersler, kongre ve toplantılar yapılmaktadır. Bütün üniversitelerimizde, sosyal sorumluluk kulüpleriyle, öğrencilere sürdürülebilir-ekolojik kampüs bilinci yerleştirilmeye çalışılmıştır. Tüm üniversitelerimiz yeterli yeşil alana sahip olduğu görülmüştür. Peyzaj ve çevre düzenine, yöresel bitki ve hayvan türlerini koruma faaliyetlerine oldukça önem verilmiştir. Ancak yeşil çatı sisteminin kullanımında gereçli olmamaktadır. Yeşil çatı sistemleri, çok fazla bitki çeşitliliği ve görsel çekiciliğe katkı sunmakla birlikte, iyi derece 1sı yalıtımı ve yağmur suyu depolama imkanına olanak vererek hem enerji hem de su yönetimine büyük katkılar sağlamaktadır. Son yıllarda revaçta olan ve yeni kullanım alanları bulan yeşil çatı sistemi, sadece Özyeğin Üniversitesi tarafından kullanılmıştır.

Çalışmada kullanılan 6 ana kriter bazında kıyaslama yapıldığında Şekil 13' de "sürdürülebilir eğitim" kategorisi en yüksek puana sahipken, "sürdürülebilir ulaşım" ise en düşük puana sahiptir. Üniversite kampüslerinde, doğaya zarar veren fosil yakıtlı ulaşım araçları kullanılmaktadır. Kampüs içinde çevreye dost bisiklet, elektrikli tramvay ve servis araçları kullanımına teşvik edilerek üniversitelerimizin sürdürülebilir ulaşım bilinç düzeyi artırılabilir.

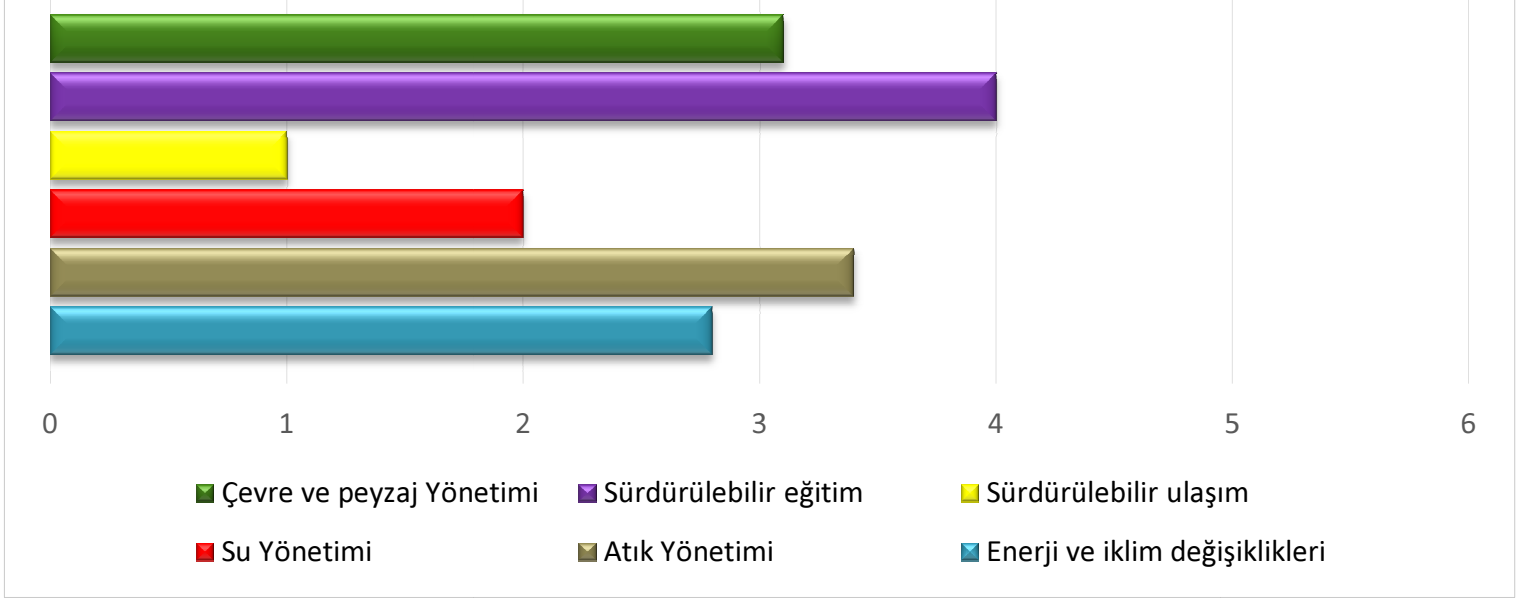

Şekil 13. Alt1 ana kriterlerin önem dereceleri.

Üniversitelerimizde yeşil bina uygulamalarının yeterli seviyede olmadığı görülmüştür. Yeşil binalar enerji tasarruf özelliği ile önem kazanan yapılar arasında yer almaktadır. Yeşil bina değerlendirme sistemlerinden Enerji ve Çevre Dostu Tasarımda Liderlik sertifikasyonu (LEED) ve uluslararası yeşil bina sertifikasyonuna (BREEAM) sahip yeşil binalar tasarlanmış sürdürülebilir kampüs sayısı ülkemizde az sayıdadır. Yeşil bina uygulamaları ile kampüs içinde daha verimli ısıtma ve soğutma sistemlerinin tasarımı ile enerji verimliliği ve yenilenebilir enerji kullanımı, etkili aydınlatma gibi bina sürdürülebilirlik parametreleri konularında optimum ve yenilikçi çözümler gerçekleştirilebilir. $\mathrm{Bu}$ çerçevede üniversitesanayi ve üniversite-kamu iş birliği ile yeşil bina uygulamalarına yönelik teşvikler arttırılarak, ülkemizdeki üniversite kampüslerinin sürdürülebilir-ekolojik kampüs olma seviyeleri arttırılabilir.

Ülkemiz yenilenebilir enerji kaynaklarından olan güneş enerjisi ve rüzgâr enerjisi açısından oldukça zengin olmasına rağmen bu enerji kaynaklarının üniversite kampüslerimizde kullanımı yeterli seviyede olmadığı görülmüştür. Bulundukları bölgenin iklim ve çevre koşullarını göz önüne alarak, yenilenebilir enerji (güneş, rüzgâr, biyogaz vb.) potansiyeli ve 
y1llık enerji talepleri belirlenerek, üniversitelerin optimum enerji tasarrufuna yönelik enerji planları geliştirilebilir. Sürdürülebilir-ekolojik kampüs çalışmalarına proje destekleri verilerek, üniversite kampüslerinin sürdürülebilir - ekolojik kampüs olma özellikleri daha üst seviyelere taşınarak, üniversite kampüslerinde yaşam kalitesi attırılabilir.

İleriki çalışmalarda, sürdürülebilir-ekolojik üniversite kampüslerinde akademik personel, idari personel ve öğrencilere yönelik anket çalışmaları uygulanarak kampüslerde iyileştirme ve geliştirmeye yönelik çalışmalar yapılabilir. Sürdürülebilir-ekolojik üniversite kampus bileşenlerinin yaşam kalitelerinin arttırılması amacı ile farkındalık yaratma anketleri, kampüsler arası yarışmalar, konuyla ilgili sempozyumlar vb. bilimsel aktivitelerle iyileştirmeler sağlanabilir. Anket sonuçları istatistiksel analizlerle sayısal veriler ışığında gelişmeler irdelenebilir. Böylece eksikler ortaya konarak iyileştirmeler için kısa, orta ve uzun vadeli planlar yapılabilir. Ülkemizdeki tüm üniversitelerin sürdürülebilir-ekolojik kampüs olma yolundaki gelişimlerinin izlenmesi ile gelecekteki hedefleri doğrultusunda planlamalar yapılabilir ve böylede dünyadaki sürdürülebilir-ekolojik kampüslerin sıralamasında üst sıralarda yer alması sağlanabilir.

\section{Kaynaklar}

[1] http://cevreonline.com/cevre-kirliliginin-nedenleri/, (07.06.2018).

[2] Ozon Tabakasinı incelten maddelere dair Montreal Protokolü, (1990). http://iklim.cob.gov.tr/iklim/AnaSayfa/montrealptotokolu.aspx?sflang=tr,(19.01.2018.

[3] Türkeş, M., İklim Değişikliğiyle Savaşım, Kyoto Protokolü ve Türkiye, Mülkiye Dergisi, 32, 101-131, (2014).

[4] Engagement and the communication spectrum, (2017), http://www. stepstosustainability.com, (20.01.2018).

[5] Parmesan, C., Ecological Evolutionary Responses to Recent Climate Change. The Annual Review of Ecology, Evaluation, and Systematics, 37, 637-669, (2006).

[6] Sürdürülebilir Kalkınma için Coğrafi Eğitim ile ilgili Luzern (İsviçre) Deklarasyonu, (2007). http://www.igu-cge.org/Charters-pdf/turkish.pdf, (20.01.2018).

[7] Suwartha, N. Ve Sari, R., Evaluating UI GreenMetric as a tool to support green universities development: assessment of the year 2011 ranking, Journal of Cleaner Production ,61, 46-53, (2013).

[8] http://greenmetric.ui.ac.id/criterian-indicator/, (30.01.2018).

[9] www.sustainability-year-in-review.stanford.edu, (30.12.2018).

[10] https://sustainability.berkeley.edu/water, (17.12.2017).

[11] https://www.nottingham.ac.uk/sustainability/transport/sustainabletransport.aspx, (23.12.2017).

[12] Innovative and cost- saving solar solutions for colleges and universities, (2016). https://us.sunpower.com/sites/sunpower/files/solar-higher-education-collegesuniversities_0.pdf, (02.01.2018).

[13] Wright, T. S., Definitions and frameworks for environmental sustainability in higher education, Higher Education Policy, 15, 2, 105-120, (2002).

[14] Shriberg, M., Institutional assessment tools for sustainability in higher education: strengths, weaknesses, and implications for practice and theory, Higher Education Policy, 15, 2, 153-167, (2002).

[15] Alshuwaikhat, H. M. ve Abubakar, I., An integrated approach to achieving campus sustainability: assessment of the current campus environmental management practices, Journal of Cleaner Production, 16, 16, 1777-1785, (2008). 
[16] Luis Velazquez, N. M., Sustainable university: what can be the matter?, Journal of Cleaner Production, 14, 9-11, 810-819, (2006).

[17] Ragazzi, M. ve Ghidini, F., Environmental sustainability of universities: critical analysis of a green ranking. International Conference on Technologies and Materials for Renewable Energy, Environment and Sustainability, Energy Procedia, International conference on Technologies and Materials for Renewable Energy, Environment and Sustainability, 119,111-120, Beirut, Lebanon, (2017).

[18] Erdede, S.B. ve Bektaş, S., Ekolojik açıdan sürdürülebilir taşınmaz geliştirme ve yeşil bina sertifika sistemleri, Harita Teknolojileri Elektronik Dergisi, 6, 1, 1-12, (2014).

[19] https://yesilkampus.boun.edu.tr/, (18.12.2017).

[20] Crozdanic, L., ENR2 is the largest project in Arizona to earn a LEED Platinum certification, (2016). https://inhabitat.com/enr2-is-the-largest-project-in-arizona-toearn-a-leed-platinum-certification/, (07.06.2018).

[21] Erdede, S.B., Erdede, B. And Bektaş, S., Sürdürülebilir Yeşil Binalar Ve Sertifika Sistemlerinin Değerlendirilmesi, V. Uzaktan Algılama ve Coğrafi Bilgi Sistemleri Sempozyumu, İstanbul, Türkiye, (2014).

[22] https://www.eur.nl/en/about-eur/profile/strategy/erasmus-sustainable/operations, (07.06.2018).

[23] Tan, H., Chen , S., Shi, Q., ve Wang, L., Development of green campus in China, Journal of Cleaner Production, 64, 646-653, (2014).

[24] Tiyarattanachai, R. ve Hollmann, N., Green Campus initiative and its impacts on quality of life of stakeholders in Green and Non-Green Campus universities, 1-17, SpringerPlus 5, (2016).

[25] Saadatian, O., Bin Sopian, K. ve Salleh, E., Adaptation of sustainability community indicators for Malaysian campuses as small cities, Sustainable Cities and Society, 6, 40-50, (2013).

[26] Dagiliute, R. ve Liobikiene, G. University contributions to environmental sustainability: challenges and opportunities from the Lithuanian case, Journal of Cleaner Production, 108, 891-899, (2015).

[27] Olszak, E., Composite indicators for a sustainable campus-Design rationale and methodology: The case of the Catholic Institute of Lille, Ecological Indicators, 23, 573-577, (2012).

[28] Hajrasouliha, A., Campus score: Measuring university campus qualities. Landscape and Urban Planning, 166-176, (2017).

[29] Yoshida, Y., Shimoda, Y. ve Ohashi, T., Strategies for a sustainable campus in Osaka University. Energy and buildings, 147, 1-8, (2017).

[30] Amr, A. I., Kamel, S., El Gohary, G. ve Hamhaber, J., Soil as an Ecological Factor for a Sustainable Campus Landscape, Procedia Environmental Sciences, 34, 1-12, (2016).

[31] A. Parasuraman, Valarie A. Zeithaml and Leonard L. Berry., A., Conceptual Model of Service Quality and Its Implications for Future Research, Journal of Marketing, 49, 4, 41-50, (1985).

[32] Bhuian, S. N., Sustainability of Western branch campuses in the Gulf Region: Students' perspectives of service quality, International Journal of Educational Development, 49, 314-323, (2016).

[33] Fahhihi, V., Hessami, A. ve Ford, D., Sustainable campus improvement program design using energy efficiency and conservation, Journal of Cleaner Production, 107, 16, 400-409, (2015). 
[34] Li, X., Tan, H. ve Rackes, A., Carbon footprint analysis of student behavior for a sustainable university campus in China, Journal of Cleaner Production, 106, 97-108, (2015).

[35] UI GreenMetric Dünya Üniversiteler Siralaması, (2017). http://greenmetric.ui.ac.id/wp-content/uploads/2015/07/UI-GreenMetric-Guideline2017_Turkish-Rev.1.pdf. (21.01.2018).

[36] http://www.sabanciuniv.edu/tr/kampus-hayati/peyzaj, (15.12.2017).

[37] http://gazetesu.sabanciuniv.edu/tr/2013-01/kampuste-cevreci-ulasim, (06.06.2018).

[38] https://univerlist.com/blog/en-yesil-8-universite/, (06.06.2018).

[39] Kumbur, H., Özer, Z., Özsoy, H. D., ve Avci, E. D., Türkiye' de geleneksel ve yenilenebilir enerji kaynaklarının potansiyeli ve çevresel etkilerinin karşılaştırılması, Yeksem 2005, III. Yenilenebilir Enerji Kaynakları Sempozyumu ve Sergisi, Mersin, (2005).

[40] http://web.beun.edu.tr/greenmetrics/, (30.12.2017). 